\title{
PENGARUH KEPEMILIKAN MANAJERIAL, KEPEMILIKAN INSTITUSIONAL, PROFITABILITAS DAN MANAJEMEN LABA TERHADAP KUALITAS LABA
}

\author{
Roswita Mergia \\ E-mail: roswitamergia44614@gmail.com
}

Sulistyo

Supami Wahyu Setiyowati

Program Studi Akuntansi, Fakultas Ekonomika Dan Bisnis, Universitas PGRI Kanjuruhan Malang

\begin{abstract}
Abstrak
Tujuan atas penelitian ini yakni menjelaskan serta menganalisis bagaimana pengaruh kepemilikan manajerial, kepemilikan institusional, profitabilitas dan manajemen laba terhadap kualitas laba. Jenis penelitian yakni digunakan data kuantitatif. Populasi yang digunakan pada penelitian ini ialah perusahaan manufaktur sektor industri barang konsumsi yang terdaftar di Bursa Efek Indonesia periode 2017-2019. Sampel yang digunakan ialah 20 perusahaan dengan periode pengamatan selama 3 tahun. Motode dalam penentuan sampel yakni digunakannya motode purposive sampling. Analisis pengelolaan data yang digunakan pada penelitian ini adalah regresi linear berganda menggunakan spss versi 22. Hasil analisis telah memberikan simpulan yakni kepemilikan menejerial, kepemilikan institusional, profitabilitas dan manajemen laba secara simultan mempengaruhi kualitas laba. kepemilikan manajerial tidak memengaruhi terhadap kualitas laba, kepemilikan institusional negativ mempengaruh kualitas laba, profitabilitas secara persial mempengaruh kualitas laba, menejemen laba secarah parsial berpengaruh terhadap kualitas laba.
\end{abstract}

Kata kunci: Kualitas Laba, Kepemilikan Manajerial, Kepemilikan Institutional, Profitabilitas Dan Manajemen Laba.

\begin{abstract}
The purpose of this research is to explain and analyze how manegerial ownerhip, institutional ownerhip, profitability and profit managemet influenc on profit qualiti. This typeh of researc is used quatitative data. The population used in this study is a manufacturing company in the consumer goods industry sector listed on the Indonesia Stock Exchage for the period 2017-2019. The samples used were 20 companies with an observation period of 3 years. Motode in the determination of samples is the use of motode purposive sampling. The date managemnt analysis used in this study was multiple linear regression using spss version 22 . The results of the analysis have concluded that managerial ownerhip, institutional owneship, profitability and profit menegement simultaneously affect the quality of profit. managerial ownership does not affect the quality of profit, negativ istitutional ownersip affects the qualiti of profit, profitability persially affects the quality of profit, profit management partially affects the quality of profit.
\end{abstract}

Keywords: Profit quality, Managerisal ownership, institusional ownership, profitability and Profit Management 


\section{PENDAHULUAN}

Persahaan merupakan rangkaian dari berbagai jenis aktivitas produksi pada pengelolaan sumber daya perusahaan dalam rangka penyedia barang ataupun jasa untuk para konsummen sebagai salah satu tujuan utama perusahaan yakni memperoleh laba serta pemuas kebutuhan bagi masyarkat. Tujuan utama perusahaan memaksimalkan laba (profit), semua keuntungan akan didapat oleh pemegang saham dimasa yang akan datang. Perushaan didirikan dengan harapan memperoleh laba yang tinggi.

Fenomena yang terjadi pada perusahaan manufaktur sektor industri barang konsumsi yang terdaftar di Bursa Efek Indonesia yaitu, indeks saham turun. Sejak awal tahun hingga sekarang, indeks saham barang komsumsi turun $12.68 \%$, penurunan disebapkan karena turunnya saham emiten akibat sentiment negative dalam bentuk rancangan menaikkan biaya cukai sebesar 23\% untuk tahun 2020, dikarenakan Pendukung utama indeks saham adalah PT HMSP dan PT GGRM. Dampak negative saham emiten berlaku dalam waktu yang singkat. Dikarenakan tingginya peminat rokok di Negara kita. Ditinjau dari sisi geografis Negara kita, rokok bisa menjadi konsumsi yang tinggi dari setiap kalangan. Naiknya harga rokok di Indonesia masih tergolong kecil ketimbang beberapa Negara tetangga. (Kontan.co.id, Rabu September 2019).

Observasi sebelumnya yang dilakukan Pratiwy, F. R., \& L.W, (2019) kepemilikan manajerial mempengaruhi kualitas laba. Pratama \& Sunarto, (2018) membuktihkan bahwa kepemilikan institusional tidak berpengaruh signifikan terhadap kualitas laba. Laoly dan Herawaty, (2019) menggambarkan profitabilitas berpengaruh negative pada kualitas laba. Nanang \& Tanusdjaja, (2019) manajemen laba mempengaruhi kualitas laba.

Hasi darilpeneliti terdahulu terjadi ketidak konsisten. Observasih dilakukan untuk mengetahui apakah hasil akan diperoleh nantinya dapat mendekati hasil atau berbeda dengan peneliti terdahulu dan menambahkan variabel independen, sehingga peneliti ingin mengujikembali “Pengaruh Kepemilikan Manajerial, Kepemilikan Institusional, Profitabilitas Dan Manajemen Laba Terhadap Kualitas Laba Pada Perusahaan Manufaktur Sektor Industri Barang Konsumsi Yang Terdaftar Di Bursa Efek Indonesia Periode 2017-2019".

\section{TINJAUAN PUSTAKA}

\section{Kualitas Laba}

Kualitas laba ialah kapasitas informasi yang tersedia bagi public yang bisa menunjukan bagaimana profit bisa memengaruhi investor dalam pengambilan keputusan untuk melihat nilai perusahaan Keuntungan bermutu ialah keuntungan yang menggambarkan kelanjutan laba dimasah yang akan datang, ditinjau dari jenis akrual dank as, serta menggambarkan progres laba sebenarnya (Wulasary, 2013).

\section{Kepemilikan Manajerial}

Kepemilikan manajerial menunjukan adanya peran ganda seorang manajer dalam suatu perusahaan, yakni sebagaih manajer dan pemegang saham. Semakin besar KM sehingga manajemen lebih berupaya menguntungan pemegang saham yang notabene adalah mareka sndiri. Wibowoh, (2017) 


\section{Kepemilikan Institusional}

Kepemilikan institusional menunjukan lembaga yang bisa memberikan kenaikkan kontrol yang maksimal atau menentukan saham prusahaan yang dimiliki instansi.

\section{Profitabilitas}

Return On Assets ialah ukuran seberapa besar efektivitas manajemen dalam mengelolah aset dan modal yang dimiliki perusahaan untuk menhasilkan laba dari aktivitasnya yang dilakukan perusahaan pada periode akuntansi tertentu. Semakin besar ROA suatu bank, semakin besar pula tingkat keuntungan yang dicapai bank, dan semakin baik pula posisi bank dari segi penggunaan aset. Halim, (2015)

\section{Manajemen Laba}

Manajemen laba mendefinisikan sebagai "intervensi manajemen dengan berencana dalam bentukpenentuan laba, biasanya untuk memenuhi tujuan pribadi". Suatu bentuk penyimpangan dalam sistim pembentukanlaporan keuangan, yakni mempengaruhi tingkat laba yang ditampilkan dalam laporan keuangan. Subramanyam dan Wild, (2013)

\section{HIPOTESIS PENELITIAN}

\section{Pengaruh Kepemilikan Manajerial, Kepemilikan Institusional, Profitabilitas Dan Manajemen Laba} Terhadap Kualitas Laba.

Kepemilikan manajerial memiliki kerkaitan yang cukup dengan kualitas laba. Prayasa Irwan dan Hermiyetti, (2018) membuktikan bahwa KM, KI \& ML memengaruhi KL secara signifikan. Secarah simultan profitabilitas mempengaruhi KL kualitas laba (Risdawati dkk, 2015).

$\mathrm{H}_{1}$ : Kepemilikan Manajerial, Kepemilikan Institusional, Profitabilitas \& Manajemen Laba Berpengaruh Secara Simultan Terhadap Kualitas Laba.

\section{Pengaruh kepemilikan manajerial terhadap kualitas laba}

Kepemilikan manajerial ialah proporsi pemegang saham dari pihak manajemen yang secara aktife ikut dalam pengambilan keputusan perusahaan. Beberapah penelitian (Soly dan Wijaya, 2017) mengatakan bahwah KM tidak memengaruhi kualitas laba, tetapi tidak sejalan dengan hasil (Pratiwy, F. R., \& dan L. W, (2019) yang menyatakan kepemilikan Manajerial berpengaruh negative terhadap kualitas laba.

$\mathrm{H}_{2}$ : Kepemilikan Manajeria Barpengaruh pada “Kualitas Laba"

\section{Pengaru Kepemilkan Institusional Terrhadap Koalitas Laba}

Kepemilikan institusional ialah saham yang dimiliki dari insttansi keuangan atau institusy Pertiwy dkk, (2017) . Hasil penelitian Latif, (2017) mengindikasikan bahwa kepemilikan institusional keterkitan positif terhadap kualitas laba. Menurut Dipanusa, (2013) kepemilikan institusional mempengaruhi kualitas laba.

$\mathrm{H}_{3}$ : Kepemilikan Institusional Berpengaruh Terhadap Kualitas Laba.

\section{Pengaruh Profitabilitas Terhadap Kualitas Laba}


Kemampuan perusahaan dalam mencari laba atau keuntungan pada suatu periode tertentu merupakan profitabilitas menurut Kasmir, (2015). Ada beberapa penelitian terdahulu yang dilakukan Anggara, F. K., (2019) mengatakan ROA memengaruhi KL. Akan tetapi, tidak sesuai dengan Laoli \& Herawati, (2019) profitabilitas berpengaruh negatif terhadap kualitas laba. Maka dirumuskan hipotesis $\mathrm{H}_{4}$ : Profitabilitas Berpengaruh Terhadap Kualitas Laba

\section{Pengaruh Manajemen Laba Terhadap Kualitas Laba}

Manajemen laba didefinisikan sebagai "intervensi dengan tujuan tertentuh oleh manajemen dalam proses penentuan laba biasanya untuk memenuhi tujuan sendiri" K. R. Subramanyam, (2013). Shuardi, (2017) mengindikasikan bahwa manajemen laba berpengaruh negatif signifikan terhadap kualitas laba, sementara Nanang dan Tanusdjaja, (2019) manajemen laba berpengaruh positif terhadap kualitas laba.

$\mathrm{H}_{5}$ : Manajemen Laba Berpengaruh Terhadap Kualitas Laba

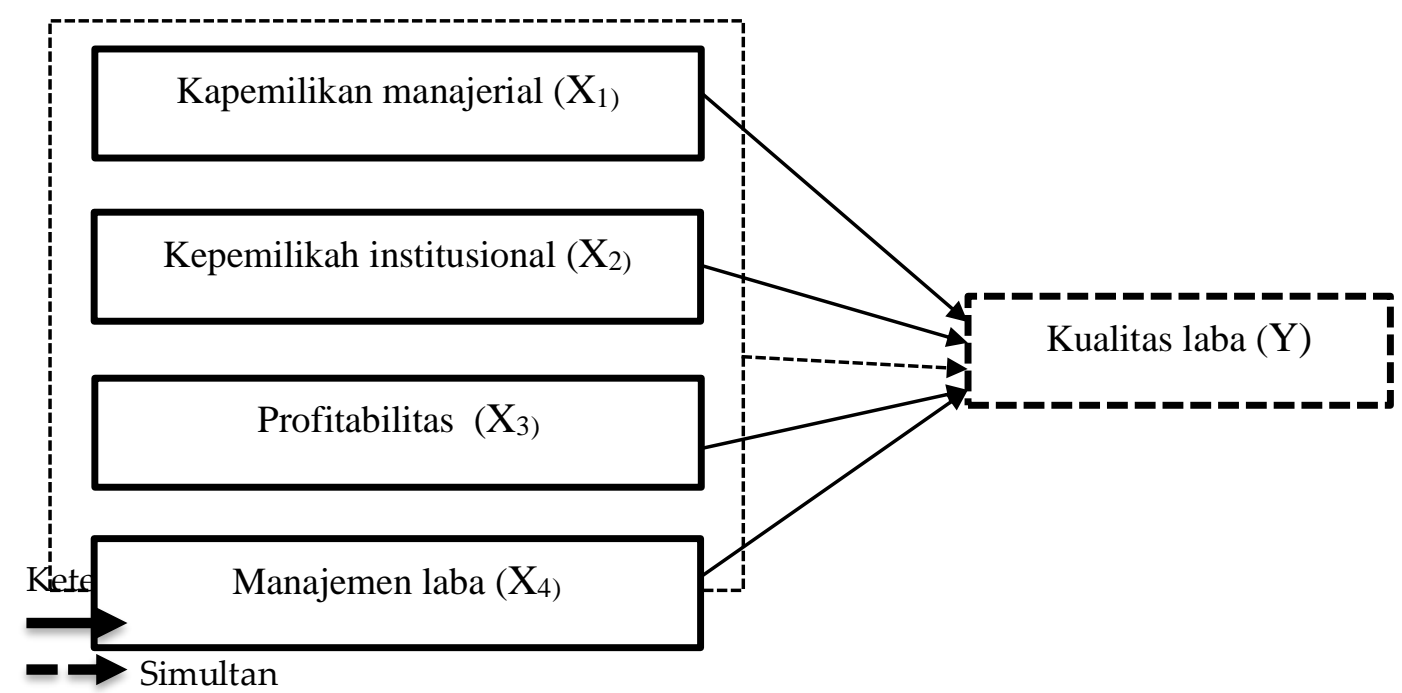

\section{Keterangan Hipotesis}

$\mathrm{H}_{1}$ : kepemiliken menajeral, kepemiliken institusional, profytabilitas \& menajemen laba berpengarh tarhadap kualites laba

$\mathrm{H}_{2}$ : kepmilikan manajerial berpngaru terhedap kualits laba

$\mathrm{H}_{3}$ : kepamilikan institusional berpengarh tarhadap kualitas laba

$\mathrm{H}_{4}$ : profitabilitas berpengaruh terhadap kualitas laba

$\mathrm{H}_{5}$ : manajemen labah berpegaruh terhadep kualits laba

\section{METODE PENELITIAN}

Medel pengkajian yakni kuantitatif. Teknik terambilnya shampel digunakan purposive sampling, yakni meneliti pada populasi dan sampel. Teknik analisis data menggunakan regresi linier berganda, untuk memberikan keterkaitan variabal indepnden yang totalnya lebih dari satuh trhadap variebel dependen. Penelitian menggunakan analisis regresi liniar bergandah digunahkan untuk mengujih hipoteis mengatakan KM, KI, ROA dan ML secarah simultan dan persial berpengaruh terhadap kualitas laba. 
HASIL

\section{Uji Asumsi Klasik}

Uji Normalitas

Hasil uji asumsi klasik normalitas mengambarkan Asymp Sig (2-tailed) senilai 0.200 melebihi 0.05. Menunjukan bahwa variabel penganggu atau varibel yang tidak diteliti memeiliki distribusi normal.

Uji Multikolinieritas

Untuk menegetahui ada atau tidaknya problem multikolinieritas dengan menetukan nilai VIF (Variance Inflation Faktor), apabila nilai VIF $<10$ atau nilai tolerane $>0,1$ berati tidak terjadi multikolinieritas.

Uji Autokorelasi

Hasil uji asumsi klasik autokorelasi menunjukan nilai Runt Test Asymp Sig (2-tailed) sebesar 0,997 atau lebih besar > dari 0,5, sehingga tidak terjadi gejala autokorelasi.

Uji Heteroskedastisitas

Hasil uji asumsi klasik heterokedastisitas dengan pendekatan metode spearman Rank menunjukan bahwa semua variabel bernilai tidak signifikan karena nilai Sig (2-tailed) diatas 5\%, sehingga dapat disimpulkan bahwa tidak terjadi heterokedastisitas pada model regresi.

\section{Coefficientsa.}

\begin{tabular}{|c|l|c|c|c|}
\hline \multicolumn{2}{|c|}{ Model } & \multicolumn{2}{c|}{ Unstandaradized Coeffisients } & $\begin{array}{c}\text { Standardized } \\
\text { Coeffisients }\end{array}$ \\
\hline & & B & Std. Error & Beta \\
\hline 1 & (Constant) & $-0,298$ & 1,252 & 0,071 \\
\hline & LNX1 & 0,104 & 0,190 & $-0,403$ \\
\hline & LNX2 & $-0,837$ & 0,292 & 0,321 \\
\hline & LNX3 & 0,357 & 0,152 & 0,282 \\
\hline & LNX4 & 0,187 & 0,085 & \\
\hline
\end{tabular}

Sumber: hasil output SPSS diolah peneliti tahun 2020

Uraian atas tabel diatas:

$\mathrm{Y}=-0,298+0,104 \mathrm{X}_{1}+-0,837 \mathrm{X}_{2}+0,357 \mathrm{X}_{3}+0,187 \mathrm{X}_{4}+\mathrm{e}$

Nilai konstanta sebesar -0,298, memiliki artinya bahwa jika semua variabel bebas (X) yakni KM, KI, ROA dan ML bernilai 0 (nol) atau konstanta maka kualitas laba akan menurun menjadi -0,298.

Koefisien regresi X1 $\rightarrow$ Y 0.104 nilai positif. Terindikasih kepemilikan manajerial keterkaitan positif pada kualitas laba. Artinya jika kepemilikan manajerial ditingkatkan 1 persen, maka kualitas laba akan naik 0,104 persen, dengan asumsi variabel tidak berubah.

Koefisien regresi X2 $\rightarrow$ Y $-0,837$ bernilai negative. Terindikasi kepemilikan institusional hubungan negative pada kualites labah. Apabila variabel kapemilikan meningkat satuh persen, makah kualita laba menurun $-0,837$ persen. 
Koefisien regresi $\mathrm{X} 3 \rightarrow \mathrm{Y}$ positif 0,357 . Terindikasi profitabilitas berkaitan negatif pada kualitas laba. Bermaknah variabel ROA ditingkatkan 1 persen, hingah koalitas laba meningkat 0,357 persen, dengan asunsi varibel tidak beruba.

Koefisien regresi $\mathrm{X} 4 \rightarrow \mathrm{Y}$ positif 0,187. Terindikasih manajemen laba kertekaitan pada kualitas laba. Bermakna jika variabel manajemen laba ditingkatkan 1 persen, hingah kalitas laba meningkat 0,187 persen, dengan asumsy variabel tida bergantih.

\section{Uji Hipotesis}

\section{Uji Simultan (Uji Statistik F)}

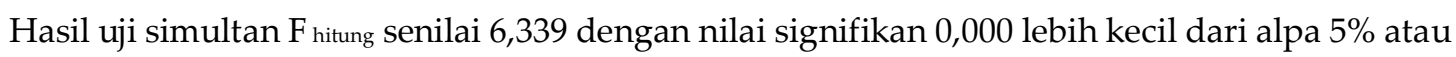
0,05. Hal tersebut mengambbarakan bersama-sama (simultan) KL memengaruhi oleh kepemilikn menejerial, kepamilikan institusi0nal, profitabilitas \& manajemen laba, diterimah

\section{Uji Parsial (Uji Statistik t)}

Hipotesis kedua mengindikasikan nilai X1 0,587 lebih besar dari alpa 5\%. Artinya kepenilikan manajerial tidak berpengaruh padah kualitas laba, ujihipitesis ditolak

Hipotesi ketigah mengindikasikan kepemilikan institusional 0,007 lebih kecil dari alpa 5\%. Artinya kepemilikan institusional berpengaruh terhadap kualitas laba, diterimah.

Hasil uji hipotesis keempat terindikasih bahwa nilai profitabilitas 0,024 lebih kecil dari alpa $5 \%$. Artinya X3 hubungan positif pada kualitas laba, diterima.

Hasil uji hipotesis kelima mengindikasikan bahwa nilai manajemen laba 0,033 lebih kecil dari alpa 5\%. Artinya manajemen laba berpengaruh terhadap kualitas laba, diterima.

\section{PEMBAHASAN}

Pengaruh Kepemilkan Menejerial, Kepmilikan Intitusional, Profitabilitas \& Menejemen Laba pada Kuaitas Laba

Berdasakan hasill pangujian hipotesis dijelaskan KM, KI, ROA dan ML berpengaruh secarah simultan terhadap kualitas laba. Naik turunya koalitas labah memengaruhi perubahan kapemilikan menejerial, kepemilikn intitusional, profitabilias dan manajemen laba independen sisanya dipengaruhi oleh variabel lainyang tidak diteliti. Hasil tersebut mengindikasikan terjadi pengaruh simultan antarah variabel bebas dan variabel terikat, sehinggah kapemilikan menejerial, kepemilkan istitusional, profitabilitas \& menejemen labah memberi pengaruh cukup besar terhadap kualitas laba, karena jika penggunaan hutang semakin banyak, semakin besar pula kepercayaan kreditur terhadap perusahaan karena perusahaan mampu melunaskan hutangnya sesuai dengan jangka waktu yang telah ditentukan dengan demikian investor akan semakin percaya sehingga para investor menanamkan modal mareka pada perusahaan tersebut, dengan begitu tingkat kualitas laba akan semakin baik..

Tingkat kepemilikan saham oleh pihak manajemen yang secara aktif terlibat dalam pengambilan keputusan ialah kepemilikan manajerial. Tidak berpengaruhnya KM terhadap kualitas laba dikarenakan oleh rendahnya tingkat kepemilikan oleh manajer didalam struktuc kepemilikan perusahaan.

Saham yang dimiliki pihak institusional yakni kepemilikan isntitsiunal dan merupakan salah satu alat untuk mengurangi konflik agen antarah pihak manajemen dan kepemilikan perusahaan. 
Semakin besar kepemilikan oleh institusional maka akan semakin besar peran institusional dalam mekanisme corporate governance, shingga aspek pengawasan oleh pihak institusional terhadap kinerja manajemen semakin meningkat.

ROA ialah kinerja industri yang menimbang rasio keuangn dalammenghasikan profit dan membantu aktive yang dimiliki-Nya merupakan profitabilits. Rasio profitabilitas umumnyah digunahkan yakni Retrn On Aset. Semakin besar retun on aset suatuh perusahan makin besar pulah tingkat proft yang dicapai dengan profitabilitas tinggi juga mampunyai koefisien respon laba yang lebih besar dibandingkan dengan perusahaan yang memiliki profitabilitas rendah. Jikaindustry mendapatkan laba menonjol, investor minat untuk menjalankaninvestasih.

Suatu tindakan yang mengatur waktu pengakuan pendapatan, beban keuntungan atau kerugian agar mencapai informasi laba tertentu yang diinginkan tanpa melanggar ketentuan yang distandar akuntansi merupakan manajemen laba.

Observasi didukung oleh Prayasah dan Hermiyetti, (2018) membuktikan bahwa kapemilikan menejerial, kpemilikan instituhsional, \& menejemen labah memengaruhi padakualitas laba. (Risdawaty \& Subowo, 2015) memberikan profitabilitas secara simultan berpengaruh terhadap kualitas laba. Nadirsyah dan Muharran, (2015) menunjukan kepemilikan manajerial dan kepemilikan institusional secara persial berhubungan terhadab koalitas laba.

\section{Pengaruh Kepemilikan Manajerial Terhadap Kualitas Laba}

KI tidak mempengaruhi KL. Hal tersebut mengindikasi rendahnya tingkat kepemilikan oleh manajer didalam struktur kepemilikan instansi dan kecilnya proporsi kepemilikan saham yang dialokasikan untuk manajer, secara empiris ditemukan bukti bahwa perusahaan yang kepemilikannya lebih menyebar membagikan imbalan lebih besar kepada manajemen sehingga dapat mengurangi motivasi manajer untuk memalsukan data. (Soli \& Wjaya, 2017) KM tidak memengaruh pada KL, dikarekankan bagian menejemen belum memprioritaskan prestasihnya atauh masih bertindak untuk kepentingan pribadih bukan untuk bertindak demi kepentngan principal. Namun tidak sejalan penelitian Pratiwy, F. R., \& Fitri, L. W., (2019) KM memengaruh negative pada koalitas laba.

\section{Pengaruh Kepemilikan Institusional Terhadap Kualitas Laba}

Kepemilikan institusional mempengaruhih negative pada kualitas laba. Disebapkan karena perusahaan belum mampu mengelolah biaya operasionalnya dengan baik, sehingga akan menimbulkan pada laba instansi Jika kepemilikan institusional tingih, hingah koalitas laba menurun dan sebaliknya. Penelitian kembali menunjukan adanya keterbatasan penerapan Good Corporate Governance, yakni kepemilikan institusional terhadap pengawasan perusahaan. Dipanusah, (2013) membuktikan bahwa kepemilikan institusional berpengaruh negative terhadap kualitas laba. Namun tidak sejalan dengan penelitian Abdul dkk, (2017) dan Latif, (2017) kpemilikan institusihonal berkaitan positive padakualitas laba.

\section{Pengaruh Profitabilitas Terhadap Kualitas Laba}

Profitabilitas mempengaruhi pada kualitas laba. Profitabilitas dapat diukur dengan Return On Asset. Penelitian membuktikan besarnya laba yang dihasilkan perusahaan dapat pengembangan profitabilytasnya, dalam artih industry mencapaih menaikkan profit, dibilang perusahan berupayah 
menjalankan sumberdayah dimilikinya secara efektiv dan efisen hinggah mengapaih tinggihnya keuntungan. Laba dijadikan penentu baik atau buruknya kinerja suatu perusahaan dalam mengelolah modal yang dimiliki. Anggara, F. K. (2019) mengatakan profitabilitas berpengaruh positif terhadap kualitas laba. Namun, tidak sejalan penelitian Laoli dan Hrrawati, (2019) bahwa profitabilitas keterkaitan terhadapt kualitas laba.

\section{Pengaruh Manajemen Laba Terhadap Kualitas Laba}

Manajemen labah mempengaruhi kualitas laba. mengindikasikanbahwa manajemen laba dilakukan dalam bentuk menaikan laba untuk mencapai target laba tertentu, disimpulkan kualitas laba menjadi sangat penting karenah dapat dipengaruhih oleh manajemen laba Martani dkk, (2017). Indikasi ML suatuh perusahaan semakih memperkuat asumsi bahwa dalam hal pelaporan laba operasional perusahaan terdapat suatuh tindakan manipulasih laba yang tercermin dalam tindakan yang dilakukan. Tinggihnya laba bisa dibilang bermutu, bila dilaporkan profit tersebuth bisa memperoleh pemakai laporan keuangan untuk membentuk pertimbangan bagi kelangsungan hidup perusahaan, dengan demikian diprediksi bahwa menejemen labah memiliki memengarh tkualitas labah. Suardi, (2017), membuktikan bahwa manajemen laba berpengaruh negative terhadap kualita laba, tidak sejalan hasil penelitian Nanang dan Tanusdjaja, (2019) ML hubungan positive terhadap kualitas laba.

\section{KESIMPULAN}

Sesuai analisis serta penjabaran diberikan simpulan yakni secara simultan, kepemilikan manajerial, kepemilikan institusional, profitabilitas dan manajemen laba berpengaruh terhadap kualitas laba. Sedangkan secara parsial KM tida memengaruhi KL. KI, ROA dan ML secara parsial hubungan terhadap kualitas laba.

\section{SARAN}

Sebaiknya penelitih selanjutnya melakukan penelitian lebih lanjut lagih yang berkaitan dengan factor-factor yang mempengaruhi kualitas laba dengan jumlah sampel yang lebih banyak dan menambahkan jumlah variabel dan periode sehingga memperkuat hasil peneliti untuk selanjutnya.

\section{Daftar Pustaka}

Abdullah, M. W., \& Suardi, S. 2017. Pengaruh Overvalued Equities Dan Earnings Management Terhadap Kualitas Laba Dengan Good Corporate Governance Sebagai Variabel Moderasi. Assets: Jurnal Ekonomi, Manajemen dan Akuntansi, 7(1), 86-103.

Dipanusa, B. A. 2013. Pengaruh Investment Opportunity Set (IOS), Komisaris Independen, Kepemilikan Manajerial, Dan Kepemilikan Institusional Terhadap Kualitas Laba. Doctoral dissertation, Universitas Pendidikan Indonesia.

Kasmir. 2015. Pengantar Manajemen Keuangan. Jakarta: Kencana Prenda Media Grup.

Laoly, A. N., \& Herawaty, V. 2019. Pengaruh Profitabilitas, Growth, Leverage, Operating Cycle Dan Prudence Terhadap Kualitas Laba Dengan Firm Size Sebagai Variabel Moderasi. In Prosiding Seminar Nasional Cendekiawan (pp.2-39).

Halim, A. 2015. Manajemen Keuangan Bisnis Konsep dan Aplikasinya, Jakarta; Mitra Wacana Media.uoted.

Martani, D., Siregar, V., Wardhani, R., Farahmita, A., \& Tanujaya, E. 2017. Akuntansi Keuangan Menengah. Jakarta: Salemba Empat.

Nadirsyah, N., \& Muharram, F. N. 2015. Struktur Modal, Ggod Corporate Governance Dan Kualitas Laba. Jurnal Dinamika Akuntansi dan Bisnis, 2(2), 184-198. 
Nanang, A. P., \& Tanusdjaja, H. 2019. Pengaruh Corporate Governance Terhadap Kualitas Laba Dengan Manajemen Laba Sebagai Variabel Intervening Pada Perusahaan Manufaktur Yang Terdaftar Di BEI Periode 2015-2017. Jurnal muara ilmu ekonomi dan bisnis, 3(2), 267-288.

Pratiwy, F. R., \& Fitri, L. W. 2019. Pengaruh Good Corporate Governance (GCG), Reputasi KAP Dan Struktur Modal Terhadap Kualitas Laba (Studi Kasus Pada Perusahaan Manufaktur Di Bursa Efek Indonesia Periode 2013-2017). Doctoral Dissertation, lain Surakarta.

Prayasa, I., \& Hermiyetti, H. 2018. Analisis Faktor-Faktor Yang Mempengaruhi Kualitas Laba. QUALITY: Jurnal Manajemen dan Akuntansi, 5(20), 62-77.

Pratama, A. D., \& Sunarto, S. 2018. Struktur Modal, Komisaris Independen, Kepemilikan Manajerial, Kepemilikan Institusional, Dan Ukuran Perusahaan Dan Terhadap Kualitas Laba. Dinamika Akuntansi Keuangan dan Perbankan, 7(2).

Risdawaty, I. M. E., \& Subowo, S. 2015. Pengaruh Struktur Modal, Ukuran Perusahaan, Asimetri Informasi, dan Profitabilitas Terhadap Kualitas Laba. Jurnal Dinamika Akuntansi, 7(2), 109-118.

Soly, N., \& Wijaya. N. 2017. Faktor-Faktor Yang Mempengaruhi Kualitas Laba Pada Perusahaan Manufaktur. Jurnal Bisnis Dan Akunatnsi, 19(1), 47-55.

Suardy, A. 2017. Pengaruh Overvalued Equities Dan Earnings Management Terhadap Kualitas Laba Dengan Good Corporate Governance Sebagai Variabel Moderasi. Assets Ekonomi, Manajemen dan Akuntansi, 7(1). 86-103.

Subramanyam, K. R, dan Wild, John J. 2013. Analisis Laporan Keuangan. Edisi 10, Buku 1. Jakarta: Salemba Empat.

Wulasary, Yeni. 2013. Pengaruh Invesment Opportunity Set, Likuiditas dan Leverage Terhadap Kualitas Laba. Pada Perusahaan Manufaktur Yang Terdaftar di BEI.

Wibowo. 2017. Manajemen Kinerja. Edisi Kelima. Depok Pt. Raja Grafindo Persada.

https://investasi.kontan.co.id/news/indeks-saham-sektor-barang-konsumsi-turun-begini-pendapatanalis. 